\title{
Association of Protein Energy Wasting with Income in CKD Stage 3 Patients
}

\author{
Anita Saxena, Amit Gupta \\ Department of Nephrology Sanjay Gandhi Post Graduate Institute of Medical Sciences, Lucknow, India \\ Email: anitimmy@yahoo.com, anitimmy@sgpgi.ac.in, amitgupt@sgpgi.ac.in
}

Received 8 August 2015; accepted 22 August 2015; published 25 August 2015

\begin{abstract}
Protein energy wasting (PEW) is a major challenge in CKD. Objective: To assess PEW in predialysis patients on their first visit to a nephrologist. Methods: Three day dietary intake of 484 CKD stage 3 patients was taken. Appetite was assessed with ADAT. Patients were divided into groups based on appetite and BMI. Results: Male and female parameters are serum albumin 3.7 \pm 0.84/3.68.8 \pm $0.81 \mathrm{~g} / \mathrm{dL}$, total protein $7.02 \pm 1.27 / 6.94 \pm 1.26 \mathrm{~g} / \mathrm{dL}$, creatinine $4.68 \pm 4.19 / 3.74 \pm 3.36 \mathrm{mg} \%$ creatinine clearance $33.22 \pm 30.48 / 37.55 \pm 33.87 \mathrm{ml} /$ minute, BMI $22.60 \pm 4.29 / 23.43 \pm 4.77 \mathrm{~kg} / \mathrm{m}^{2}$ energy $/ \mathrm{kg} 16.97 \pm 0.65 / 16.8 \pm 0.64$, protein $\mathrm{g} / \mathrm{kg} 0.65 \pm 0.28 / 0.64 \pm 0.30$, carbohydrate $\mathrm{g} / \mathrm{kg}$ $2.98 \pm 1.54 / 2.98 \pm 0.1 .36$, fat $\mathrm{g} / \mathrm{kg} 2.98 \pm 0.23 / 2.79 \pm 0.22$, respectively. As appetite decreased, dietary protein and energy intake decreased significantly. Appetite in males and females: Average $14.46 \%, 4.13 \%$, poor $9.7 \%, 18.18 \%$, anorexic $13.2 \%, 7.4 \%$. Income had strong correlation with BMI (p 0.000), dietary protein (p 0.000), energy (p 0.000) and carbohydrate (p 0.000). Appetite correlated with creatinine ( $p$ 0.019), dietary energy, protein, carbohydrate and fat $(p 0.000)$ intake. BMI correlated (p 0.000) with fat, carbohydrate, energy and creatinine clearance. ANOVA showed significant difference within and between appetite groups in energy, protein, fat, carbohydrate, creatinine clearance ( $p$ 0.000) and serum albumin (p 0.025). There was significant difference in protein ( $p 0.026)$, energy intake (p 0.000) and creatinine clearance (p 0.038) within and between BMI groups. Based on income, there was significant difference among groups in BMI (p $0.000)$, energy ( $p 0.019)$, protein ( $p$ 0.031) and albumin (0.001).
\end{abstract}

\section{Keywords}

Protein Energy Wasting, Appetite, Income, BMI, Chronic Kidney Disease

\section{Introduction}

In chronic kidney disease (CKD) progressive decline of glomerular filtration rate (GFR) is associated with significant reduction in food intake. Approximately one third of chronic dialysis patients suffer from fair or poor appetite which is related directly to poor patient outcome [1]-[3].

Appetite regulation in renal disease is a complex network of synergistic and antagonistic interactions among hormones, peptides, and cytokines which modulate neuro-chemical systems involved in feeding and energy balance. This is confounded and influenced by other factors such as the dialysis treatment, length of treatment, the modality of dialysis, age, psycho-social Issues, and co-morbid conditions. Appetite regulation involves play 
of several hormones like ghrelin and neuropeptide YY as an appetite stimulant, and cholecystokinin, glucagonlike peptide-1 as appetite inhibitors, leptin, a potent appetite inhibitor; the vagal system; and the brain, which integrates the stimuli in the hypothalamus area. In nondialyzed chronic renal failure patients and in maintenance dialysis patients, anorexia is related to accumulation of anorexigenic compounds, inflammatory cytokines, and alterations in appetite regulation, such as amino acid imbalance, which increases the transport of free tryptophan across the blood-brain barrier thus creating a hyperserotoninergic state which is associated with low appetite.

Treatment of anorexia involves counseling, starting dialysis treatments in uremic chronic kidney disease patients, increasing the dialysis dose, and possibly using appetite stimulants. However, it is not clear whether and to what extent a reduced appetite is related to the elements of MICS, especially inflammation, in these persons. Anorexia may indeed be a key component in the development and maintenance of PEM, inflammation, and MICS in these patients. An abnormally low appetite per se may be a risk factor in dialysis patients for such unfavorable outcomes as erythropoietin hyporesponsiveness, poor QoL, and increased mortality and hospitalization [4]. In a study on 331 maintenance hemodialysis patients (MHD) patients 62\% reported normal (good to very good) appetite, 38\% reported diminished appetite (fair to poor). With this background we conducted a study using self-reported appetite, body mass index and income as indicators of protein energy wasting (PEW) in predialysis patients on their first visit to a nephrologist.

\section{Methods}

This was a prospective, cross sectional and observational study conducted in the out-patient department. A total of 480 (348 male and 140 female) patients in CKD 3 stage patients were included in the study. Inclusion criteria were first visit of a CKD patient to a nephrologist referred by non-nephrologist physician. Data were collected between year 2013 and 2014. Inclusion criteria for selection of patients were: 1) chronic kidney disease (CKD) patients referred by non-nephrologist physician to a nephrologist; 2) patient was visiting a nephrologist for the first time; and 3) it was not a follow-up visit. Since patients were referred by a non nephrologist physician therefore on their first visit, the biochemical tests which were available from medical record were serum creatinine, albumin, total protein, calcium, and urinary protein.

Evaluation of dietary intake: Three days dietary intake was taken. Dietary intake was taken with the help of standard measuring cups and bowls in an interview. The patients were shown bowls (of different capacities) and cups and were asked to identify the bowl and cup which represented their food intake. Patients were shown portion sizes in order to get as close to their actual dietary intake. Dietary intake was assessed from 3-day diet, interview assisted, recalls administered concurrently with the ADAT. Three days dietary intake was taken by a dietician in a structured dietary interview and the response was noted on proformas. Dietary energy, protein, fat, carbohydrate, calcium and phosphorus intake was analyzed using standard standard National Institute of Nutrition (NIN) Hyderabad table for nutrient values of foods (NIN 1991).

\subsection{Measures of Nutritional Status}

Subjective assessment of appetite: The Appetite and Diet Assessment Tool (ADAT) [5] was used to determine appetite on first visit of the patient. Self reported appetite was assessed by using a simple questionnaire. The assessment was done in an interview by a dietician with Appetite and Diet Assessment Tool (ADAT) [4]. The assessment was interview based. The first three ADAT questions were related to appetite. The responses to the first question-during the past week, how would you rate your appetite-adhered to a 5-point Likert scale: 1) very good, 2) good, 3) fair, 4) poor and 5) very poor. The second question was if there had been a change in appetite in the past week and the third question was if appetite had increased, remained the same, or decreased [5]. Patients were divided into four groups depending upon self reported appetite: normal, average, poor and anorexic.

Anthropometric measurements included height in centimeters and body weight in kilograms. Patients were divided into four groups based on body mass index (BMI) [6]. Patients were divided into four groups based on BMI: normal BMI $>23 \mathrm{~kg} / \mathrm{m}^{2}$, overweight BMI $>23 \mathrm{~kg} / \mathrm{m}^{2}<27 \mathrm{~kg} / \mathrm{m}^{2}$, obese BMI $\geq 27 \mathrm{~kg} / \mathrm{m}^{2}$ and underweight $\mathrm{BMI}<18 \mathrm{~kg} / \mathrm{m}^{2}$. Blood pressure was recorded.

Results: the biochemical profile of the patients was male and female is given in Table 1. In males and females serum albumin was $3.7 \pm 0.84 / 3.68 .8 \pm 0.81 \mathrm{~g} / \mathrm{dL}$, total protein $7.02 \pm 1.27 / 6.94 \pm 1.26 \mathrm{~g} / \mathrm{dL}$, creatinine $4.68 \pm$ $4.19 / 3.74 \pm 3.36 \mathrm{mg} \%$ creatinine clearance $33.22 \pm 30.48 / 37.55 \pm 33.87 \mathrm{ml} /$ minute respectively. BMI was 
$22.60 \pm 4.29 / 23.43 \pm 4.77 \mathrm{~kg} / \mathrm{m}^{2}$. Intake of dietary energy $/ \mathrm{kg} / \mathrm{d}$ was $16.97 \pm 0.65 / 16.8 \pm 0.64$, protein $\mathrm{g} / \mathrm{kg} / \mathrm{d}$ $0.65 \pm 0.28 / 0.64 \pm 0.30$, carbohydrate $\mathrm{g} / \mathrm{kg} / \mathrm{d} 2.98 \pm 1.54 / 2.98 \pm 0.1 .36$, and fat $\mathrm{g} / \mathrm{kg} 2.98 \pm 0.23 / 2.79 \pm 0.22$, for males and females respectively (Table 2). Urinary protein was $3.64 \pm 1.37 \mathrm{mg} \%$ in males and $3.39 \pm 11.46 \mathrm{mg} \%$ in females. Dietary intake according to BMI is given in Table 3. Energy intake was less than recommended dietary intake (30 - $35 \mathrm{kcal} / \mathrm{kg} / \mathrm{d}$ ). The deficit was $16-17 \mathrm{kcals} / \mathrm{kg} / \mathrm{d}$ but protein intake was according to recommended dietary intake i.e. $6.0 \mathrm{~g} / \mathrm{kg} / \mathrm{d}$. Out of 480 patients, serum albumin levels of 357 patients were available 254 male 103 female, out of which serum albumin of 161 patients was below $3.8 \mathrm{~g} / \mathrm{dL}$ and of 196 was above 3.8 $\mathrm{g} / \mathrm{dL}$. However, mean serum albumin was less than $3.8 \mathrm{~g} / \mathrm{dL}$, a criterion for diagnosing protein energy wasting (PEW).

Dietary calcium intake was low. However low serum calcium level was within normal range (normal range $8.5-10.2 \mathrm{mg} / \mathrm{dL})$ ) in males but not in females. Although dietary phosphorus intake was within recommended intake (800 - $1000 \mathrm{mg} / \mathrm{d} \mathrm{KDOQI),} \mathrm{the} \mathrm{serum} \mathrm{phosphorus} \mathrm{was} \mathrm{above} \mathrm{normal} \mathrm{range:} 2.7$ - $4.6 \mathrm{mg} / \mathrm{dL}$.

Appetite and dietary intake: 162 (male126 female 36) patients had normal appetite and 325 (male 222, female103) had average to poor appetite (Table 4). As appetite decreased dietary protein and energy intake decreased significantly (Table 3). Out of 480 patients, $0.20 \%$ males and $26.2 \%$ females reported normal appetite, $14.5 \%$ males and $4.16 \%$ females reported average appetite, $16.6 \%$ males and $9.79 \%$ females, and $13.3 \%$ males and 7.5\% females were anorexic (Table 4). Income had strong correlation with BMI (p 0.000), dietary protein (p

Table 1. Anthropometric and biochemical profile of males and females.

\begin{tabular}{|c|c|c|c|c|c|c|c|c|c|c|c|c|}
\hline & 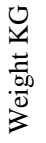 & $\begin{array}{l}\sum_{0} \\
=0 \\
=00 \\
\pm=1\end{array}$ & 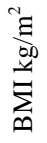 & 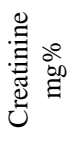 & 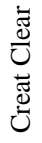 & 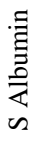 & 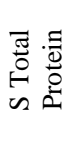 & $\sum_{\infty}^{\pi}$ & $\frac{r}{\omega}$ & $\bigcup_{\infty}^{\pi}$ & $\frac{a}{n}$ & 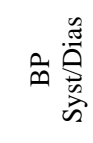 \\
\hline$\Sigma$ & $\begin{array}{l}\infty \\
0 \\
\dot{ \pm} \\
+1 \\
+1 \\
0 \\
0 \\
\dot{-}\end{array}$ & 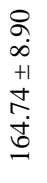 & 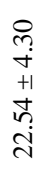 & 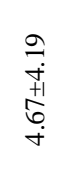 & $\begin{array}{l}\text { ए? } \\
\dot{m} \\
+1 \\
\dot{p} \\
\dot{m}\end{array}$ & $\begin{array}{l}\infty \\
\infty \\
0 \\
+1 \\
\\
\text { n் }\end{array}$ & $\begin{array}{l}\hat{y} \\
\text {-1 } \\
+1 \\
0 \\
0\end{array}$ & 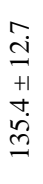 & 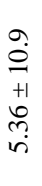 & $\begin{array}{l}\hat{\infty} \\
\sigma \\
+1 \\
\varphi \\
\infty \\
\infty\end{array}$ & 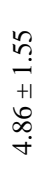 & 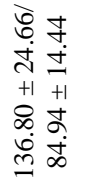 \\
\hline 工 & 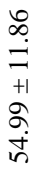 & 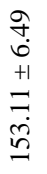 & 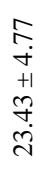 & $\begin{array}{l}\mathscr{D} \\
m \\
m \\
+1 \\
+ \\
\dot{N}\end{array}$ & $\begin{array}{l}\infty \\
m \\
m \\
+1 \\
\text { ஸे } \\
\text { mे }\end{array}$ & $\begin{array}{l}-\infty \\
\infty \\
0 \\
+1 \\
\infty \\
\emptyset \\
\dot{\infty}\end{array}$ & 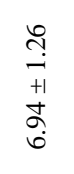 & 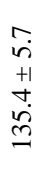 & $\begin{array}{l}\hat{0} \\
0 \\
+1 \\
0 \\
⿱ 乛 \\
\dot{\sigma}\end{array}$ & 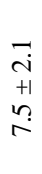 & 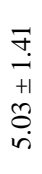 & 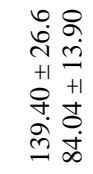 \\
\hline
\end{tabular}

M: Male; F: Female; D: Dietary; Cho: Carbohydrate; K: Potassium; Na: Sodium; Ca: Calcium; P: Phosphorus; Creatclear: Creatinine clearance; S: serum.

Table 2. Nutrient intake of males and females.

\begin{tabular}{|c|c|c|c|c|c|c|c|c|c|c|}
\hline ڤึ & 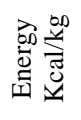 & 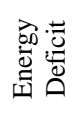 & 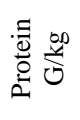 & 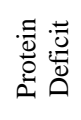 & 虽 & 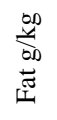 & $\stackrel{\pi}{z} \underset{a}{0}$ & $\stackrel{v}{a}$ & $\begin{array}{l}\stackrel{\infty}{E} \\
\underset{U}{U} \\
0\end{array}$ & $\stackrel{\infty}{a} \stackrel{\infty}{a}$ \\
\hline$\Sigma$ & 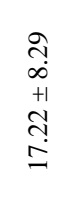 & $\begin{array}{l}\text { సे } \\
\infty \\
+1 \\
\infty \\
\infty \\
\\
-1\end{array}$ & 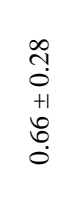 & $\begin{array}{l}\stackrel{\infty}{N} \\
+1 \\
\stackrel{2}{0} \\
\dot{0}\end{array}$ & $\begin{array}{l}\stackrel{ }{\overrightarrow{1}} \\
\text { i } \\
+1 \\
\stackrel{1}{7} \\
\vec{m}\end{array}$ & 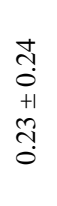 & 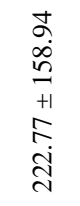 & 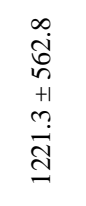 & 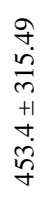 & 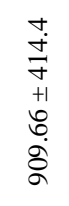 \\
\hline 工 & $\begin{array}{l}0 \\
0 \\
+1 \\
+1 \\
\infty \\
0 \\
\dot{\omega}\end{array}$ & \begin{tabular}{l}
0 \\
0 \\
+1 \\
+1 \\
\multirow{1}{7}{} \\
$\infty$ \\
-1
\end{tabular} & $\begin{array}{l}0 \\
0 \\
0 \\
+1 \\
+1 \\
0 \\
0\end{array}$ & $\begin{array}{l}0 \\
0 \\
0 \\
+1 \\
ت \\
ت \\
0\end{array}$ & 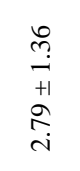 & 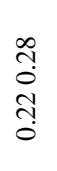 & 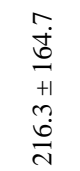 & 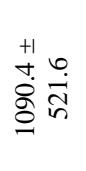 & 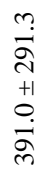 & $\begin{array}{l}\infty \\
\infty \\
\infty \\
\infty \\
m \\
+1 \\
+ \\
\infty \\
\infty \\
\infty\end{array}$ \\
\hline
\end{tabular}

M: Male; F: Female; D: Dietary; Cho: Carbohydrate; K: Potassium; Na: Sodium; Ca: Calcium; P: Phosphorus; Creat clear: Creatinine clearance; S: serum. 
Table 3. Energy and protein intake based on Body Mass Index (BMI).

\begin{tabular}{cccc}
\hline BMI & Normal & Underweight & Severely Underweight \\
\hline N\% & $52.8 \%$ & $15 \%$ & $5.71 \%$ \\
\hline Energy Intake $\mathrm{kcal} / \mathrm{kg}$ & $17.2 \pm 9.0$ & $17.0 \pm 10.0$ & $15.91 \pm 11.1$ \\
Protein Intake $\mathrm{g} / \mathrm{kg} / \mathrm{d}$ & $0.6 \pm 0.34$ & $0.5 \pm 0.4$ & $0.56 \pm 0.44$ \\
\hline
\end{tabular}

Table 4. Appetite, protein and energy intake.

\begin{tabular}{ccccc}
\hline Varible/Sex & $\begin{array}{c}\text { Normal } \\
\mathrm{N}(\mathrm{m} / \mathrm{f}) 1 / 126\end{array}$ & $\begin{array}{c}\text { Average } \\
\mathrm{N}(\mathrm{m} / \mathrm{f}) 70 / 20\end{array}$ & $\begin{array}{c}\text { Poor } \\
\mathrm{N}(\mathrm{m} / \mathrm{f}) 88 / 47\end{array}$ & $\begin{array}{c}\text { Anorexic } \\
\mathrm{N}(\mathrm{m} / \mathrm{f}) 64 / 36\end{array}$ \\
\hline Protein g/kg /Male & $0.79 \pm 0.23$ & $0.58 \pm 0.17$ & $0.50 \pm 0.20$ & $0.27 \pm 0.17$ \\
Protein g/kg /Female & $0.79 \pm 0.23$ & $0.56 \pm 0.16$ & $0.48 \pm 0.15$ & $0.29 \pm 0.20$ \\
Energy cal/kg /Male & $21.57 \pm 7.85$ & $25 \pm 3.70$ & $12.36 \pm 4.26$ & $6.92 \pm 4.36$ \\
Energy cal/kg /Female & $21.19 \pm 5.81$ & $14.67 \pm 3.09$ & $12.79 \pm 3.92$ & $7.25 \pm 3.95$ \\
\hline
\end{tabular}

0.000), energy (p 0.000) and carbohydrate (p 0.000).

\subsection{Association of Self-Reported Appetite with Other Parameters}

Appetite correlated with creatinine (p 0.019), dietary energy, protein, carbohydrate and fat (p 0.000) intake. BMI correlated (p 0.000) with fat, carbohydrate, energy and creatinine clearance. Creatinine clearance was positively associated with energy intake p 0.035, carbohydrate (p 0.004), body weight (p 0.000) and BMI (p 0.000). Anova showed significant difference within and between appetite groups in energy, protein, fat, carbohydrate, creatinine clearance ( $\mathrm{p} \mathrm{0.000)}$ ) and serum albumin (p 0.025). There was significant difference in protein ( $\mathrm{p} 0.026)$ energy intake ( $p 0.000)$ and creatinine clearance (p 0.038) within and between BMI groups.

Association of income with other parameters: Income had strong correlation with BMI (p 0.000), dietary protein (p 0.000) energy (p 0.000) and carbohydrate (p 0.000). Based on income there was significant difference between groups in energy (p 0.019), protein (p 0.031), albumin (p 0.001) and BMI (p 0.000).

\section{Discussion}

PEW is a distinct condition in chronic kidney disease (CKD) patients. It is a major challenge and one of the strongest predictor of mortality in patients with CKD. PEW is multifactorial. Uremia due to decline in renal function causes reduced dietary intake, anorexia, inflammation, imbalance between anabolic and catabolic hormones and eventually poor nutritional status. These factors along with chronic infections and comorbid conditions lead to PEW [7].

Serum albumin is used for monitor nutritional status. Hypoalbuminemia may result from reduced protein and/or calorie intake, uremia, metabolic acidosis, albuminuria, inflammation, or infection. A cross sectional study on 52 patients demonstrated serum albumin levels $<3.7 \mathrm{~g} / \mathrm{dL}$ for 3 months [8]. Evidence indicates that surrogates of PEW, such as, low serum levels of albumin or inadequate protein intake, correlate with mortality. Measuring the serum levels of albumin remains the simplest test that is readily available. Indeed, a low serum albumin concentration is by far the strongest predictor of poor outcomes and mortality, at least in patients on dialysis, when compared with any other risk factor, including the traditional risk factors (hypertension, hypercholesterolemia, diabetes mellitus, and obesity) and the nonconventional risk factors (measures of anemia, mineral and bone surrogates, and dialysis modality) [9]. In our study, serum albumin levels were low (mean $3.68 \pm 0.81$ $\mathrm{g} / \mathrm{dL}$ ) indicating PEW. The United States Renal Data System (USRDS) database results have shown that every 1 $\mathrm{g} / \mathrm{dL}$ fall in the serum albumin level is associated with a $39 \%$ increase in the risk of cardiovascular death [10]. The association between serum albumin levels and mortality is highly incremental and linear. Study on 42 MHD hospitalized patients has shown that mean protein and calorie intakes were $10 \mathrm{kcal} / \mathrm{kg}$ and $0.4 \mathrm{~g}$ protein $/ \mathrm{kg}$ and during the first 48 hrs of hospitalization $14 \%$ of patients met estimated kcal needs and only $7 \%$ met their protein needs [11]. PEW sets in during CKD stage 3 or even earlier partially due to inadequate nutritional management in predialysis phase and becomes clinically evident when GFR is $<15-10 \mathrm{ml} / \mathrm{min}$ [12]. Our study population 
was in CKD stage 3 and as has been shown in results the dietary energy and protein intake was less than recommended intake, which was strongly influenced by appetite, income and creatinine clearance.

However, it is still not clear if low serum levels of albumin in patients with CKD are a surrogate of inadequate protein intake or other conditions related to PEW, such as inflammation and comorbidity [13]. Association of hypoalbuminemia with poor outcomes in non dialysis and dialysis CKD patients is not disputed. In this study though protein intake was between $0.6-0.75 \mathrm{~g} / \mathrm{kg} / \mathrm{d}$, serum albumin and energy intake was significantly low which explained that proteinuria ( $>3.0 \mathrm{~g}$ ) inflammation and low energy intake caused hypoalbuminemia. Appetite may be influenced by the elaboration of cytokines and the acute phase response. Since data were collected on the patient's first visit to a nephrologist, only basic investigations like serum creatinine, albumin and total protein were available, and CRP [14] was not available, therefore it could only be assumed that reason for low serum albumin level was underlying inflammation. ANOVA showed significant difference within and among appetite groups in energy, protein, fat, carbohydrate, creatinine clearance, and serum albumin (p 0.025). There was also significant difference in protein (p 0.026), energy intake (p 0.000), and creatinine clearance (p 0.038) within and between BMI groups.

Poor/very poor appetite was associated with lower dietary energy, protein, carbohydrate and fat (p 0.000 ) intake. BMI correlated ( $\mathrm{p} 0.000$ ) with fat, carbohydrate, energy and creatinine clearance. The dietary energy deficit was $16-17 \mathrm{kcals} / \mathrm{kg} / \mathrm{d}$ but protein intake was according to recommended dietary intake i.e. $6.0 \mathrm{~g} / \mathrm{kg} / \mathrm{d}$. Dietary protein and energy intakes are often reduced in maintenance haemodialysis patients. In this study, we found that dietary protein intake was below levels recommended by the National Kidney Foundation Kidney Disease Outcomes Quality Initiative (K/DOQI) Nutrition Guidelines $(0.6 \mathrm{~g} / \mathrm{kg} /$ day $)$ in those with low BMI and average to poor appetite. Energy intake fell below K/DOQI targets (>30\% below K/DOQI recommendations of 30 $35 \mathrm{kcal} / \mathrm{kg} /$ day), particularly among those with poorer appetite. Therefore, more detailed nutritional assessments are needed in future to help detect PEM.

Diminished appetite was also associated with decreased concentrations of biochemical markers of nutritional status such as serum albumin and serum creatinine, and with anthropometric markers. Our results confirm and extend previously published work [15]-[22]. The association of low GFRs with lower levels of nutritional parameters is potentially of substantial clinical importance. PEM is a common complication of patients undergoing maintenance hemodialysis or chronic peritoneal dialysis. The average dietary energy intake in our cohort was low, $17.0 \pm 9.0 \mathrm{kcal} / \mathrm{kg} /$ day as their creatinine clearance was $37.5 \pm 33.8 \mathrm{ml} /$ minute. These data are consistent with the hypothesis that low energy intakes are a major contributor to PEM in patients with chronic renal failure. As a corollary, maintenance of higher energy intakes in these individuals may prevent a decline in their nutritional status [23]. The associations of appetite ratings with anthropometric and co-morbidity markers, however, are new and would seem to suggest that anorexia gave rise to PEM. Sodium plays an important role in blood pressure control in CKD as a result of alterations in sodium excretion by the kidneys. Blood pressure Less than $140 / 90 \mathrm{mmHg}$ is important for retarding progression of disease. In this study blood pressure was well controlled as all the patients were on antihypertensive treatment and dietary sodium intake was $<2.4 \mathrm{~g} / \mathrm{d}$.

In our study income had strong correlation with BMI (p 0.000), dietary protein (p 0.000), energy (p 0.000) and carbohydrate (p 0.000). Based on income there was significant difference among groups in energy ( $\mathrm{p} 0.019)$, protein (p 0.031), albumin (p 0.001) and BMI (p 0.000).

Very few studies have investigated independent associations between appetite and clinical outcomes. The results of the study by Kalantar-Zadeh et al. found significant and much larger effects (greater than 2-fold) after testing for linear mortality effects across four appetite categories (i.e. very good, good, fair, and poor), and nearly a 5-fold effect after dichotomizing the categories into two groups [i.e. normal (very good and good) and anorexic (fair and poor)] [4] [15]. However, those results were derived from survival analyses using 25 deaths, whereas our analyses incorporated 792 deaths. Part of this difference could also be attributed to the much healthier cohort studied by Kalantar-Zadeh et al. as evidenced by their higher quality of life and serum albumin values. Longevity has consistently been observed in those patients with CKD who have a better nutritional status, including larger muscle mass, fat mass, better appetite, and higher protein intake [4] [15]. A 10-year cohort study has shown that serum albumin concentration is far superior as a predictor of 10-year mortality in hemodialysis patients than inflammatory markers (C-reactive protein) or the intima-media thickness of the common carotid artery [24]. PEW, therefore, seemed to be a strong predictor of mortality in patients with CKD, and improving nutritional status by dietary and non-dietary interventions could be an important step toward improving the outcomes in CKD [25]. 
This study has shown that when oral dietary intake from regular meals cannot maintain adequate nutritional status, nutritional supplementation should be administered orally, enterally, or parenterally. Nutritional supplementation has been shown to be effective in replenishing protein and energy stores. Appetite stimulants, antiinflammatory interventions, and newer anabolic agents are emerging as novel therapies [26]. According to some hypotheses, cardiac diseases such as heart failure may cause reduced appetite or anorexia and, if sufficiently severe, may independently induce muscle wasting, which is also known as cardiac cachexia [27].

Weakness of the study: This was a one point cross sectional study and patients were not followed up for subsequent changes in nutritional intake. The true effects of the impact of diminished appetite on the variables studied may be underestimated.

Conclusion: As renal function declines, appetite worsens and dietary intake decreases. Energy intake is significantly low in all groups. Low income is a risk factor for PEW in CKD. Timely and effective dietary interventions and nutritional support should correct PEW and improve outcomes in patients with CKD. Nutritional assessment is important at the time of presentation of patient to a nephrologist, followed by periodical (monthly or quarterly) assessment improvement or deterioration of existing PEW. Careful dietary intervention advising high energy oral nutritional supplements should be advised for increasing serum albumin concentration if protein intake is appropriate.

\section{References}

[1] Chazot, C. (2009) Why Are Chronic Kidney Disease Patients Anorexic and What Can Be Done about It? Seminars in Nephrology, 29, 15-23.

[2] Kensit, M. (1979) Appetite Disturbances in Dialysis Patients. The Journal of the American Association of Nephrology Nurses \& Technicians, 6, 194-199.

[3] Ginsberg, N., Fishbane, D. and Lynn, R. (1996) The Effect of Improved Dialytic Efficiencies on Measures of Appetite in Peritoneal Dialysis Patients. Journal of Renal Nutrition, 6, 217-221. http://dx.doi.org/10.1016/S1051-2276(96)90069-2

[4] Kalantar-Zadeh, K., Block, G., McAllister, C.J., Humphreys, M.H. and Kopple, J.D. (2004) Appetite and Inflammation, Nutrition, Anemia, and Clinical Outcome in Hemodialysis Patients. The American Journal of Clinical Nutrition, 80, 299-307.

[5] Burrowes, J.D., Larive, B., Chertow, G.M. and Cockram, D.B. (2005) Self-Reported Appetite, Hospitalization and Death in Haemodialysis Patients: Findings from the Hemodialysis (HEMO) Study. Nephrology Dialysis Transplantation, 20, 2765-2774. http://dx.doi.org/10.1093/ndt/gfi132

[6] WHO Expert (2004) Appropriate Body-Mass Index for Asian Populations and Its Implications for Policy and Intervention Strategies. Lancet, 363, 157-163. http://dx.doi.org/10.1016/S0140-6736(03)15268-3

[7] Kopple, J.D., Greene, T., Chumlea, W.C., Hollinger, D., et al. (2000) Relationship between Nutritional Status and the Glomerular Filtration Rate: Results from the MDRD Study. Kidney International, 57.

[8] Zimmerer, J., Leon, J., Covinski, K., et al. (2003) Diet Monotony as a Correlate of Poor Nutrition Intake among Hemodialysis Patients. Journal of Renal Nutrition, 13, 72-77.

[9] Kovesdy, C.P. and Kalantar-Zadeh, K. (2009) Why Is Protein-Energy Wasting Associated with Mortality in Chronic Kidney Disease? Seminars in Nephrology, 29, 3-14. http://dx.doi.org/10.1016/j.semnephrol.2008.10.002

[10] Martignoni, M.E., Kunze, P. and Friess, H. (2003) Cancer Cachexia. Molecular Cancer, 2, 36. http://dx.doi.org/10.1186/1476-4598-2-36

[11] Steiber, A.L., et al. (2002) Journal of Renal Nutrition, 12, 49-54. http://dx.doi.org/10.1053/jren.2002.28353

[12] Kopple, J.D., Greene, T., Chumlea, W.C., Hollinger, D., et al. (2000) Relationship between Nutritional Status And the Glomerular Filtration Rate: Results from the MDRD Study. Kidney International, 57.

[13] Friedman, A.N. and Fadem, S.Z. (2010) Reassessment of Albumin as a Nutritional Marker in Kidney Disease. Journal of the American Society of Nephrology, 21, 223-230. http://dx.doi.org/10.1681/ASN.2009020213

[14] Kovesdy, C.P., George, S.M., Anderson, J.E. and Kalantar-Zadeh, K. (2009) Outcome Predictability of Biomarkers of Protein-Energy Wasting and Inflammation in Moderate and Advanced Chronic Kidney Disease. The American Journal of Clinical Nutrition, 90, 407-414. http://dx.doi.org/10.3945/ajcn.2008.27390

[15] Kalantar-Zadeh, K., Block, G., McAllister, C.J., et al. (2004) Appetite and Inflammation, Nutrition, Anemia and Clinical Outcome in Hemodialysis Patients. The American Journal of Clinical Nutrition, 80, 299-307

[16] Burrowes, J.D., Larive, B., Cockram, D.B., et al. (2003) Effects of Dietary Intake, Appetite, and Eating Habits on Di- 
alysis and Non-Dialysis Treatment Days in Hemodialysis Patients: Cross-Sectional Results from the HEMO Study. Journal of Renal Nutrition, 13, 191-198. http://dx.doi.org/10.1016/S1051-2276(03)00069-4

[17] Lowrie, E.G. and Lew, L.N. (1990) Death Risk in Hemodialysis Patients: The Predictive Value of Commonly Measured Variables and an Evaluation of Death Rate Differences between Facilities. American Journal of Kidney Diseases, 15, 458-482. http://dx.doi.org/10.1016/S0272-6386(12)70364-5

[18] Canada USA Peritoneal Dialysis Study Group (1996) Adequacy of Dialysis and Nutrition in Continuous Peritoneal Dialysis: Association with Clinical Outcomes. Journal of the American Society of Nephrology, 7, 198-207,

[19] Avram, M.M., Mittman, N., Bonomini, L., Chattopadhyay, J., Fein, P. (1995) Markers for Survival in Dialysis: A Seven-Year Prospective Study. American Journal of Kidney Diseases, 26, 209-219. http://dx.doi.org/10.1016/0272-6386(95)90176-0

[20] Leavey, S.F., Strawderman, R.L., Jones, C.A., Port, F.K. and Held, P.J. (1998) Simple Nutritional Indicators as Independent Predictors of Mortality in Hemodialysis Patients. American Journal of Kidney Diseases, 31, 997-1006. http://dx.doi.org/10.1053/ajkd.1998.v31.pm9631845

[21] Fleischmann, E., Teal, N., Dudley, J., May, W., Bower, J.D. and Salahudeen, A.K. (1999) Influence of Excess Weight on Mortality and Hospital Stay in 1346 Hemodialysis Patients. Kidney International, 55, 1560-1567. http://dx.doi.org/10.1046/j.1523-1755.1999.00389.x

[22] Kopple, J.D., Zhu, X.F., Lew, N.L. and Lowrie, E.G. (1999) Body WEIGHT-for-height Relationships Predict Mortality in Maintenance Hemodialysis Patients. Kidney International, 56, 1136-1148. http://dx.doi.org/10.1046/j.1523-1755.1999.00615.x

[23] Kopple, J.D., Greene, T., Chumlea, W.C., Hollinger, D., et al. (2000) Relationship between nutritional status and the glomerular filtration rate: Results from the MDRD Study. Kidney International, 57, 1688-1703.

[24] Kato, A., Takita, T., Furuhashi, M., Maruyama, Y. and Hishida, A. (2010) Comparison of Serum Albumin, C-Reactive Protein and Carotid Atherosclerosis as Predictors of 10-Year Mortality in Hemodialysis Patients. Hemodialysis International, 14, 226-232. http://dx.doi.org/10.1111/j.1542-4758.2009.00432.x

[25] Kalantar-Zadeh, K., Cano, N.J., Budde, K., Chazot, C., Kovesdy, C.P., Mak, R.H., et al. (2011) Diets and Enteral Supplements for Improving Outcomes in Chronic Kidney Disease. Nature Reviews Nephrology, 7, 369-384. http://dx.doi.org/10.1038/nrneph.2011.60

[26] Ikizler, T.A., Cano, N.J., Franch, H., Fouque, D., et al. (2013) Prevention and Treatment of Protein Energy Wasting in Chronic Kidney Disease Patients: A Consensus Statement by the International Society of Renal Nutrition and Metabolism. Kidney International, 84, 1096-1107. http://dx.doi.org/10.1038/ki.2013.147

[27] Bergstrom, J. and Lindholm, B. (1998) Malnutrition, Cardiac Disease, and Mortality: An Integrated Point of View. American Journal of Kidney Diseases, 32, 834-841. http://dx.doi.org/10.1016/S0272-6386(98)70148-9 